\title{
Plains Pricklypear Is a Good Forage for Cattle
}

\author{
M. C. SHOOP, E. J. ALFORD, AND H. F. MAYLAND
}

Highlight: Singed plains pricklypear was assessed as a cattle forage. In an 84-day feeding trial, six pairs of heifers were individually fed a basal ration of hay and cottonseed meal at $\mathbf{2 . 3 \%}$ of initial bodyweight. One heifer in each pair also ate singed pricklypear offered ad libitum. Pricklypear increased total dry matter consumption $43 \%$ and weight gain $72 \%$. The heifers experienced no digestive problems during the trial or ensuing 60 days on pricklypear range. Chemical analyses and microdigestion trials indicated that digestibility of pricklypear was equal or superior to that of high quality alfalfa hay. Pricklypear contained about $40 \%$ more soluble carbohydrates than alfalfa hay, but contained only $3.4 \%$ digestible protein. Therefore, rations containing pricklypear would usually require protein supplementation. We concluded that singed pricklypear was a palatable and nutritious feed and should be evaluated as an additional forage on shortgrass range.

Most cattlemen operating under range conditions on the shortgrass plains of Colorado cannot successfully calve replacement heifers as 2-year-olds (Shoop and Hyder 1976). However, successful calving of heifers at 2 years of age instead of 3 years can increase calf production on a ranch about $10 \%$ (Pinney et al. 1972).

Heifers need to weigh at least $272 \mathrm{~kg}(600 \mathrm{lb})$ at breeding and $363 \mathrm{~kg}$ at calving for successful calving and rebreeding as 2year-olds (Bond and Wiltbank 1970; Wiltbank 1972; Clanton 1973). To meet these weight criteria, weaner heifers produced on shortgrass range must gain about $0.38 \mathrm{~kg} /$ day more during winter than is typical at present (Shoop and Hyder 1976). However, most ranchers on shortgrass range must buy energy feeds if they want to improve rate of gain of replacement heifers. Many have found this uneconomical.

Over $560 \mathrm{~kg} / \mathrm{ha}(500 \mathrm{lb} / \mathrm{acre})$ of plains pricklypear (Opuntia polyacantha Haw.) dry matter occur on some range sites in northeastern Colorado (D. N. Hyder private communication). Currently, plains pricklypear is regarded to be essentially worthless as a livestock forage, is a nuisance to man and beast, and is a barrier that prevents cattle from grazing a considerable portion of the herbage (Bement 1968) (Fig. 1).

Cattlemen have successfully fed various species of pricklypear (Opuntia spp.) for many years, both as a drouth feed and as a forage (Griffiths 1905; Griffiths 1912; Woodward et al. 1915). The Opuntia species that have been analyzed for nutrient

Authors are range scientist, Agricultural Research Service, U.S. Department of Agriculture, Fort Collins, Colorado 80523; former graduate research assistant, Range Science Department, Colorado State University, Fort Collins; and soil scientist, Agricultural Research Service, U.S. Department of Agriculture, Snake River Conservation Research Center, Kimberly, Idaho, respectively. E. J. Alford's present address is Star Route 4, Cuba, New Mexico 87013.

The study involves cooperative investigations of the Agricultural Research Service, U.S. Dep. Agr., and Colorado State Univ. (Scientific Series Paper No. 2122). Portions of this study were included in a thesis submitted by E. J. Alford as partial requirement for the MS degree.

Manuscript received April 2, 1976.

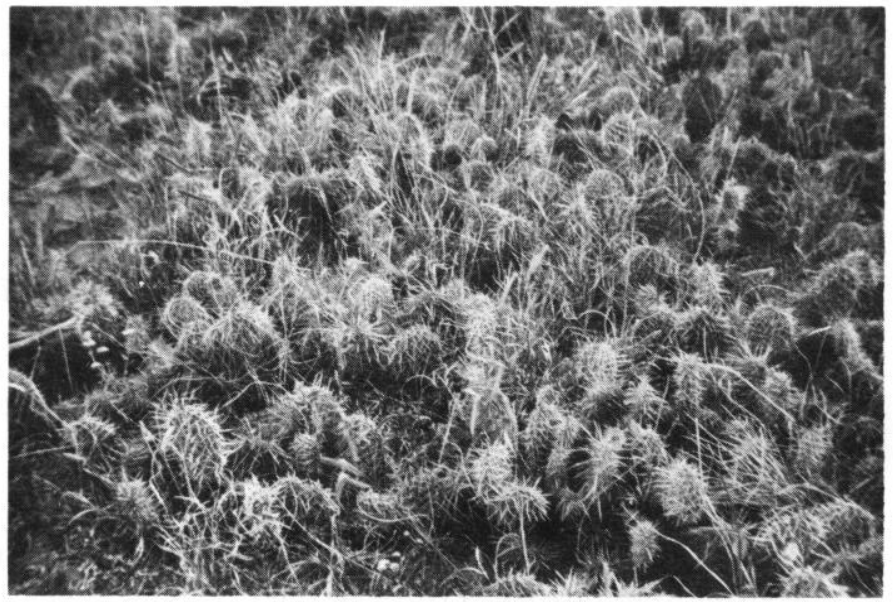

Fig. 1. Plains pricklypear interferes with grazing.

contents are high in energy and low in protein (National Research Council (NRC) 1970). However, we were unable to find any analyses or feeding trial results for plains pricklypear, even though ranchers had fed it to cattle.

The purpose of this study was to evaluate plains pricklypear (hereafter, pricklypear) as a forage and as a potential energy source for hastening growth of replacement heifers.

\section{Materials and Methods}

\section{Experimental Area}

We conducted the study on the Central Plains Experimental Range located $61 \mathrm{~km}$ ( 38 miles) northeast of Fort Collins, Colorado. Annual precipitation averages $31 \mathrm{~cm}$ (12.2 inches), $85 \%$ of which falls during the growing season, April through October. Range sites are mostly loamy plains and sandy plains. Blue grama (Bouteloua gracilis) is the dominant forage species.

\section{Feeding Trial}

Twelve yearling heifers were placed in individual drylot pens in a paired experimental design. The heifers were paired according to ownership, previous 2-month gains, conformation, breed, and weight; and were then assigned at random to treatments. They averaged $249 \mathrm{~kg}$ shrunk weight at the start of the trial.

All 12 heifers received a basal ration formulated to approximate the best winter feed condition on shortgrass range. The basal ration consisted of a grass-hay pellet fed at $2 \%$ of initial body weight, cottonseed meal (pelleted, solvent-extracted, $41 \%$ protein) fed at 0.30 $\mathrm{kg} / \mathrm{head}$ daily, and crested wheatgrass hay (Agropyron desertorum; sun-cured, full bloom) fed at $0.41 \mathrm{~kg} /$ head daily (Table 1 ). The grass-hay pellet consisted primarily of tall wheatgrass (Agropyron elongatum) and bromegrass (Bromus inermis) hay (sun-cured, overripe), which we considered to have a fair nutritional value. (Its analyses are reported under "Results."') The cottonseed meal approximated the normal level of protein supplementation on local winter 
Table 1. Average weight gain and feed intake of heifers fed singed pricklypear ration and of heifers fed only the basal diet.

\begin{tabular}{lcc}
\hline \hline Item & $\begin{array}{c}\text { Basal ration plus } \\
\text { pricklypear }\end{array}$ & $\begin{array}{c}\text { Basal } \\
\text { ration }\end{array}$ \\
\hline Heifers (number) & 6 & 6 \\
Initial weight $9 / 2 / 74(\mathrm{~kg})$ & 254 & 242 \\
Final weight $11 / 25 / 75(\mathrm{~kg})$ & 310 & 275 \\
Daily feed intake $(\mathrm{kg})$ & & \\
Basal ration: & 5.15 & 4.98 \\
$\quad$ Hay pellet & 0.30 & 0.30 \\
Cottonseed meal $(41 \% \mathrm{cp})$ & 0.41 & 0.41 \\
Crested wheatgrass hay & 5.86 & 5.69 \\
$\quad$ Sub-total & 2.53 & - \\
Pricklypear & 8.39 & 5.69 \\
$\quad$ Total & $.67 \mathrm{a}$ & $.39 \mathrm{~b}$ \\
Daily gain $(\mathrm{kg})$ & $12.5 \mathrm{c}$ & $14.6 \mathrm{~d}$ \\
\hline Feed intake $(\mathrm{kg} / \mathrm{kg})$ gain &
\end{tabular}

Means on the same line followed by different letters differ significantly at $1 \%$ level $(a, b)$ or $5 \%$ level (c,d).

range. The small amount of crested wheatgrass hay was included to alleviate lack of cud chewing, chewing of corral fences, and grinding of teeth that existed prior to its addition.

One heifer in each of the six pairs received singed pricklypear in addition to the basal ration. The pricklypear was gathered daily with a hand rake and was singed in a metal tank with a propane weed burner until its spines no longer felt sharp when touched (Fig. 2). After the pricklypear was singed, it was fed to the heifers without further processing.

The heifers received their basal ration in equal morning and evening feedings and pricklypear ad libitum. All feeds were weighed when fed and orts were weighed-back to determine feed intake. Each heifer had free access to water and plain salt at all times.

The 84-day feeding trial lasted from September 2 to November 25 and was preceded by a 2-week adaptation period. At the beginning of the trial and at 2-week intervals, all heifers were fasted for 12 hours before being individually weighed.

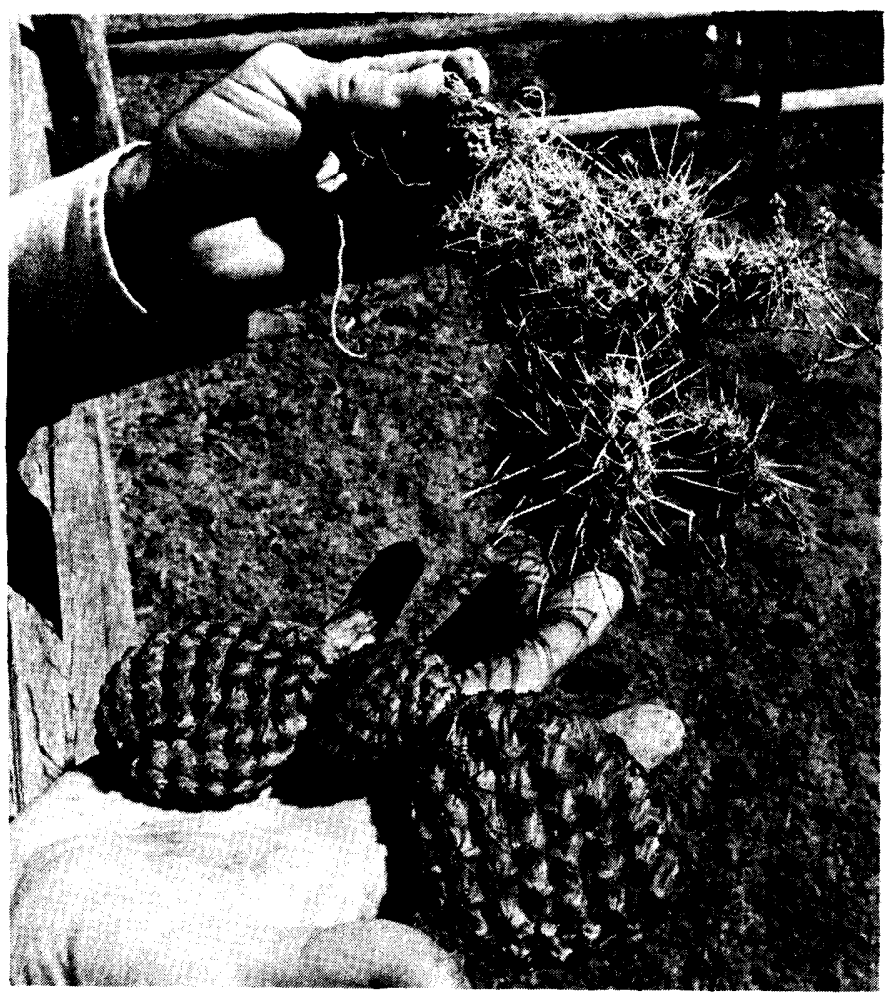

Fig. 2. Untreated pricklypear pads (above) and singed pads (below).

\section{Feed Analyses}

Samples of the singed pricklypear being fed were collected daily during the feeding trial, composited into monthly aliquots (September, October, and November), and analyzed for nutrient composition. Samples of the grass-hay pellets and alfalfa hay (Medicago sativa; sun-cured, earlybloom) were also analyzed. The alfalfa hay was used as a standard of comparison for the feeds in the feed analyses and was not fed.

Additional pricklypear samples were collected monthly after completion of the feeding trial to study the effect of season on dry matter content and mineral composition. Samples were dried at a temperature of $65^{\circ} \mathrm{C}$ for 72 hours to minimize chemical changes (Van Soest 1965; Danley and Vetter 1971).

As part of the nutrient analyses, samples were analyzed for neutral detergent fiber (NDF), acid detergent fiber (ADF), and acid detergent lignin (ADL) by the procedures outlined by Van Soest and Wine (1967) and Goering and Van Soest (1970).

Two microdigestion trials were conducted with the feeds to estimate their apparent dry matter digestibility (DMD). These included a one-stage in vitro digestion trial and an in vivo nylon bag trial. A 6-year-old Charolais cow fitted with a $10-\mathrm{cm}$ rumen fistula was used for the in vivo trial and as a source of rumen fluid for the in vitro trial. The cow was maintained on a diet of blue grama grass and a daily protein supplement of about $400 \mathrm{~g}$ of $41 \%$ protein cottonseed meal.

In vitro dry matter digestibility (IVDMD) was determined by using the first-stage procedure of Tilley and Terry (1963), as modified by Bigelow and Heflin. ' Samples were analyzed in sextuplicate.

In the in vivo trial, nylon-bag-dry-matter digestibility (NBDMD) was determined as described by Van Dyne (1962). Samples of each feed were analyzed in quadruplicate for each of two time periods of digestion. Half of the samples were removed from the cow after 16 hours of digestion and half were removed after 48 hours.

The DMD of each feed was calculated using the equation for predicting DMD described by Van Soest (1967):

$$
\begin{aligned}
\text { DMD }= & 0.98 \mathrm{~S}+\mathrm{W}\left(\frac{147.3-78.9 \log \mathrm{L}}{100}\right)-12.9 \\
& \text { Where: } \\
& \mathrm{S}=\% \text { neutral detergent solubles (cell contents) } \\
& \mathrm{W}=\% \text { cell walls }(\mathrm{NDF}) \\
& \mathrm{L}=\% \text { lignin in } \mathrm{ADF}[=(\mathrm{ADL} / \mathrm{ADF}) \times 100]
\end{aligned}
$$

Nitrogen was determined by micro-Kjeldahl analyses and a factor of 6.25 was used for calculating crude protein (A.O.A.C. 1970). Energy contents were determined by adiabatic bomb calorimetry. All feed weights are reported on an oven-dry basis. Units of measure are frequently expressed with their standard deviation.

\section{Results and Discussion}

\section{Feeding Trial}

Pricklypear was a palatable feed (Fig. 3). Individual heifers often ate the pricklypear before eating the hay pellets. The heifers fed pricklypear consumed an average of $2.53 \pm 0.59 \mathrm{~kg}$ of pricklypear daily in addition to consuming all of their basal ration, $5.86 \pm 0.73 \mathrm{~kg}$ (Table 1 ). Total daily dry matter intake by the heifers fed pricklypear averaged $3.0 \%$ of body weight. This intake compared favorably with normal intake of high quality alfalfa hay (Crampton and Harris 1969). Even considering that the pelleted portion of the basal ration probably allowed increased dry matter intake (Maynard and Loosli 1969), singed pricklypear was a highly palatable forage.

The only major factor that influenced voluntary intake of pricklypear was degree of burning of pads during singeing. All heifers promptly rejected pricklypear with spines remaining.

'Bigelow, D., and D. Heflin. 1972. Grassland Ecology Research Laboratory, Grasslands Lab., Colorado State Univ., Fort Collins. 


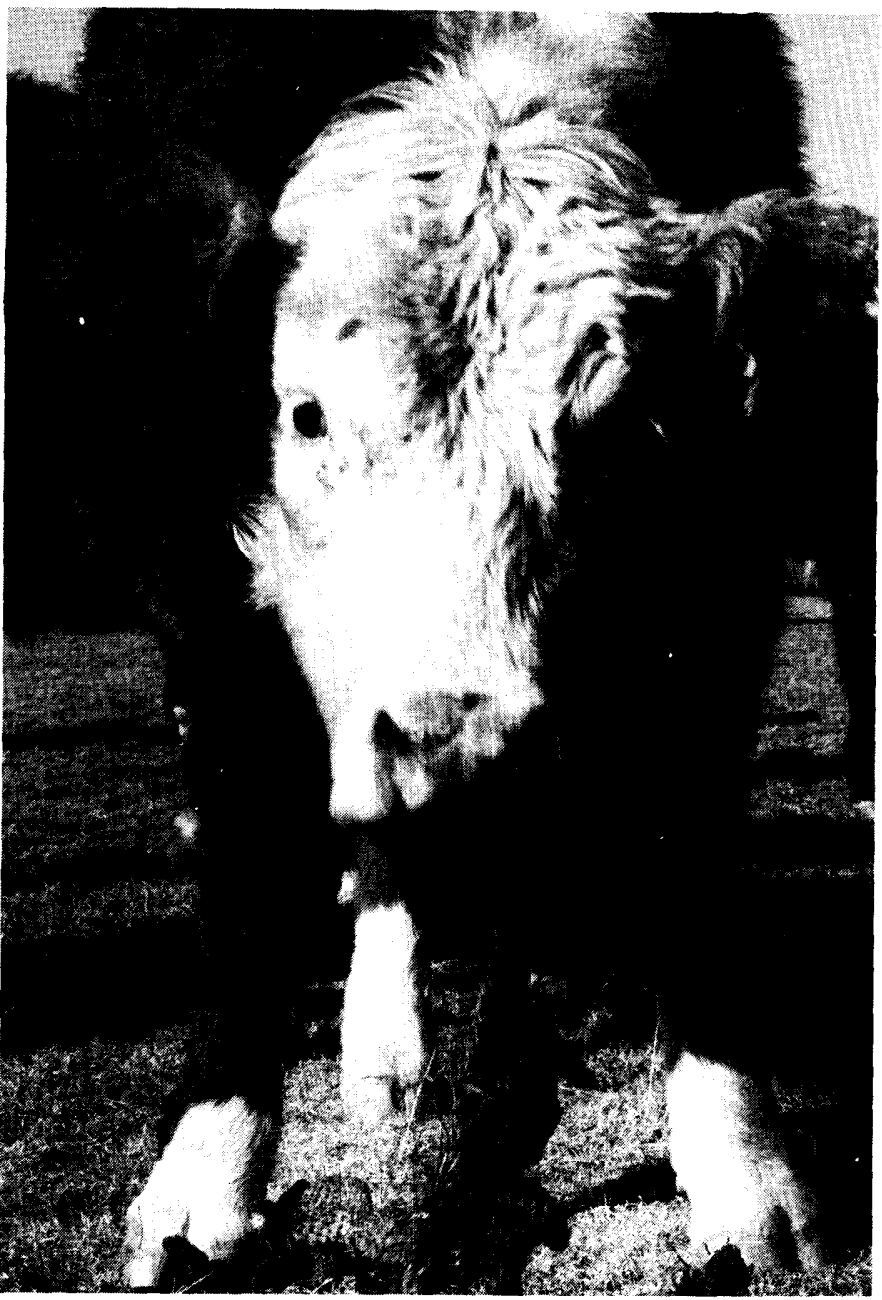

Fig. 3. Heifers ate singed pricklypear readily.

However, the glochids (minute hair-like spines), which frequently escaped burning, did not affect consumption. Heifers seemed to prefer just enough burning to remove all large spines.

A minor factor that reduced pricklypear consumption was the accumulation of soot on pricklypear. The soot accumulated during singeing whenever an excessive amount of grass and forbs was gathered with the pricklypear.

Pricklypear did not cause any apparent digestive disturbances during the trial or succeeding 60 days, even though the glochids appeared in the feces and seemed to be completely undigested. Following the feeding trial, the heifers grazed native range for 60 days. Although pricklypear was abundant, the heifers did not feed on it. In a listing of the disadvantages of Opuntia in most areas of Texas, Hoffman and Darrow (1955) stated that cattle often continued to eat it after burning stopped. However, refusal of our heifers to eat pricklypear with spines indicated that cattle fed at least a maintenance ration will not tend to eat unsinged pricklypear. Kearns (1952) reported similar results with other species of Opuntia in southern Texas, and indicated that not until cattle are tortured by hunger will they feed on Opuntia with spines.

Eight days after the start of the trial, we observed blood in the feces of the heifers fed only the basal ration. Fecal examinations revealed the presence of 60 to 430 eggs per gram produced by the Trichostrongyloid group of nematodes. In contrast, the feces of only one of the heifers fed pricklypear contained eggs, and the egg content of that was only 40 per gram.
The bloody feces ceased 6 days after starting, and after treatment with worming medicine, sulfas, and antibiotics. However, the blood was not due to nematode infestation. Instead, it was tentatively identified as being due to bovine virus diarrhea (BVD). The heifers fed pricklypear showed no symptons of BVD, probably because of somewhat better physical and nutritive condition. However, we do not know why the heifers fed pricklypear were essentially free of the nematode eggs.

Heifers fed pricklypear in addition to the basal ration gained about $72 \%$ faster than heifers fed only the basal ration (Table 1 ). Also, heifers fed pricklypear were about $17 \%$ more efficient in converting feed to body gain than those fed only the basal ration. Total weight gains were related to total feed intake.

Table 2. Protein and energy concentrations of singed pricklypear, grasshay pellets, and alfalfa hay standard.'

\begin{tabular}{lclc} 
Constituent & Pricklypear $^{2}$ & $\begin{array}{c}\text { Hay } \\
\text { pellets }^{2}\end{array}$ & $\begin{array}{c}\text { Alfalfa } \\
\text { hay }\end{array}$ \\
\hline Crude protein (CP) (\%) & $5.3 \mathrm{~b}$ & $5.7 \mathrm{~b}$ & $16.8 \mathrm{a}$ \\
Digestible protein (DP) (\%) & $3.4 \mathrm{~b}$ & $3.0 \mathrm{~b}$ & $11.4 \mathrm{a}$ \\
Gross energy (GE) (Mcal/kg) & $4.75 \mathrm{a}$ & $4.01 \mathrm{~b}$ & $4.87 \mathrm{a}$ \\
Digestible energy (DE) (Mcal/kg) & $2.61 \mathrm{a}$ & $2.08 \mathrm{~b}$ & $2.64 \mathrm{a}$ \\
\hline
\end{tabular}

Means on the same line followed by different letters differ significantly at $5 \%$ level. 'Sampled daily during 84-day feeding trial and compiled into three monthly aliquots.

\section{Feed Analyses}

\section{Protein}

Crude protein and digestible protein (DP) concentrations of pricklypear were less than one-third that of alfalfa hay, but about equal to those of the grass-hay pellets (Table 2). Young cattle and brood cows require 4 to $9 \%$ dietary digestible protein (NRC 1970). Pricklypear contained only $3.4 \%$ digestible protein. Therefore, a ration in which pricklypear was an appreciable component would require a protein supplement.

\section{Energy}

Pricklypear contained 2.6 Mcal of digestible energy per kilogram, the same amount as alfalfa hay (Table 2). Mature grama grasses (Bouteloua spp.; aerial part, fresh) contain only about 1.6 Mcal of digestible energy per kilogram (Crampton and Harris 1969). Therefore, the addition of pricklypear to the diet of cattle grazing dormant blue grama would appreciably increase their energy intake.

\section{Minerals}

The pricklypear samples contained some dust held by wrinkles of the epidermis. This was especially true of samples collected during dry weather and winter. An element in dust may be partially available to cattle, or might complex with other minerals in the digestive tract, depending on incompletely understood variables (Healy 1973).

Phosphorus content of pricklypear was about 25 to $50 \%$ of the 0.18 to $0.43 \%$ required in cattle diets (NRC 1970; Table 3). Also, the calcium:phosphorus ratio of about $36: 1$ departed greatly from an optimum ratio of 2:1 and even from a ratio of 7:1, which has been reported to be within satisfactory limits for cattle (NRC 1970). Consequently, rations with appreciable amounts of pricklypear would usually require phosphorus supplementation. The low sodium content of pricklypear would not normally be a problem if livestock salt was supplied. The concentrations of the other minerals analyzed (Table 3) appear to be within limits that would not normally lead to either deficiency or toxicity. 
Table 3. Average mineral composition of singed plains pricklypear collected monthly during winter and summer.'

\begin{tabular}{lcc}
\hline Mineral & Winter & Summer \\
\hline Nitrogen (\%) & $0.74 \pm 0.09$ & $0.74 \pm 0.09$ \\
Potassium (\%) & $1.88 \pm 0.54$ & $1.65 \pm 0.11$ \\
Magnesium (\%) & $0.77 \pm 0.08$ & $0.85 \pm 0.06$ \\
Calcium (\%) & $3.64 \pm 1.01$ & $3.38 \pm 0.29$ \\
Phosphorus (\%) & $0.10 \pm 0.01$ & $0.10 \pm 0.01$ \\
Iron (\%) & $0.12 \pm 0.01$ & $0.09 \pm 0.02$ \\
Sodium (\%) & $0.02 \pm 0.00$ & $0.02 \pm 0.00$ \\
Manganese (ppm) & $149 \pm 30$ & $266 \pm 94$ \\
Copper (ppm) & $8.3 \pm 3.5$ & $10.9 \pm 1.8$ \\
Zinc (ppm) & $25.8 \pm 4.2$ & $30.5 \pm 9.2$ \\
\hline
\end{tabular}

'Some dust contamination is inherent in this feed, especially when soil is dry and during winter. Winter $=$ Dec.-Apr.; Summer $=$ May-Oct. Standard deviation indicates variability among months.

\section{Van Soest analyses}

The Van Soest analyses generally indicated that pricklypear was a readily digestible forage. As compared to alfalfa hay, pricklypear contained only about $85 \%$ as much neutral detergent fiber, $70 \%$ as much acid detergent fiber, $80 \%$ as much acid detergent lignin, and $15 \%$ as much cellulose (Table 4). However, pricklypear contained about $80 \%$ more ash, $10 \%$ more soluble portion, 55\% more hemicellulose, and $40 \%$ more soluble carbohydrates than alfalfa hay.

The high level of soluble carbohydrates in pricklypear indicated that it has a readily available source of energy, which may combine efficiently with nonprotein nitrogen during digestion by cattle. If a pricklypear diet could be effectively supplemented with nonprotein nitrogen, crude protein could be elevated to correct the deficiency. Belasco et al. (1958) found that the nitrogen deficiency of pricklypear (species not specified) could be compensated for by foliar application of an aqueous solution of urea, a common source of nonprotein nitrogen.

Table 4. Chemical composition (\%) of singed pricklypear, grass-hay pellets, and alfalfa hay standard.'

\begin{tabular}{|c|c|c|c|}
\hline Constituent & Pricklypear $^{2}$ & $\begin{array}{c}\text { Hay } \\
\text { pellets }^{2}\end{array}$ & $\begin{array}{c}\text { Alfalfa } \\
\text { hay }\end{array}$ \\
\hline Total ash & $13.5 \mathrm{a}$ & $7.5 \mathrm{~b}$ & $7.5 \mathrm{~b}$ \\
\hline Neutral detergent fiber (NDF) & $34.0 \mathrm{c}$ & $63.1 \mathrm{a}$ & $39.6 \mathrm{~b}$ \\
\hline Acid detergent fiber (ADF) & $23.3 \mathrm{c}$ & $41.6 \mathrm{a}$ & $32.6 \mathrm{~b}$ \\
\hline Acid detergent lignin (ADL) & $7.8 \mathrm{~b}$ & $8.1 \mathrm{~b}$ & $9.5 \mathrm{a}$ \\
\hline Soluble portion & $66.0 \mathrm{a}$ & $36.9 \mathrm{c}$ & $60.5 \mathrm{~b}$ \\
\hline Hemicellulose ${ }^{3}$ & $10.7 \mathrm{~b}$ & $21.5 \mathrm{a}$ & $7.0 \mathrm{c}$ \\
\hline Cellulose $^{+}$ & $2.0 \mathrm{c}$ & $26.1 \mathrm{a}$ & $15.6 \mathrm{~b}$ \\
\hline Soluble carbohydrates; & $60.6 \mathrm{a}$ & $31.2 \mathrm{c}$ & $43.7 \mathrm{~b}$ \\
\hline
\end{tabular}

'Means on the same line followed by different letters differ significantly at $5 \%$ level. "Sampled daily and compiled into three monthly aliquots.

NDF minus ADF

${ }^{+} \mathrm{ADF}$ minus $\mathrm{ADL}$ minus ash.

i 100 minus NDF minus CP.

\section{Digestibility}

Digestion of pricklypear was more rapid than that of either hay pellets or alfalfa hay (Table 5). Of the total digestion of pricklypear during 48 hours of incubation, $80 \%$ occurred within 16 hours, whereas only $73 \%$ and $71 \%$ occurred within 16 hours for hay pellets and alfalfa hay, respectively. Greater digestion of pricklypear within 16 hours means faster digestion and indicates more rapid passage through the digestive tract. More rapid passage allows greater feed intake and improved animal gain as compared with a feed otherwise having the same nutritive qualities (Church 1975).
Table 5. Dry-matter digestibility $(\% \pm$ S.D. $)$ in vivo (NBDMD) and in vitro (IVDMD) of singed pricklypear, grass-hay pellets, and alfalfa hay standard. ${ }^{1}$

\begin{tabular}{lccc}
\hline & \multicolumn{2}{c}{ NBDMD } & IVDMD \\
\cline { 2 - 3 } & $\begin{array}{c}\text { 16hour } \\
\text { incubation }\end{array}$ & $\begin{array}{c}48 \text { hour } \\
\text { incubation }\end{array}$ & $\begin{array}{c}\text { 96hour } \\
\text { incubation }\end{array}$ \\
\hline Pricklypear $^{2}$ & $52.9 \pm 1.7 \mathrm{a}$ & $66.4 \pm 3.8 \mathrm{a}$ & $63.8 \pm 0.6 \mathrm{a}$ \\
Hay pellets $^{2}$ & $39.3 \pm 2.8 \mathrm{c}$ & $54.1 \pm 1.4 \mathrm{c}$ & $53.0 \pm 1.4 \mathrm{~b}$ \\
Alfalfa hay & $44.5 \pm 0.5 \mathrm{~b}$ & $62.9+1.1 \mathrm{~b}$ & $63.7 \pm 2.2 \mathrm{a}$ \\
\hline
\end{tabular}

'Means in the same column followed by different letters differ significantly at $5 \%$ level. "Sampled daily and compiled into three monthly aliquots.

Pricklypear and alfalfa hay did not differ significantly in dry matter digestibility in the 96-hour in vitro trial. However, in the 48-hour nylon-bag trial, pricklypear was slightly higher (3.5 percentage points) in dry matter digestibility than alfalfa hay. The NBDMD and IVDMD of grass-hay pellets were about 11 percentage points lower than that of pricklypear (Table 5).

Application of the digestion-prediction equation of Van Soest (1967), showed average dry matter digestibility values for pricklypear, grass-hay pellets, and alfalfa hay of $61 \%, 52 \%$, and $60 \%$, respectively. This compares to IVDMD values of $63.8 \%, 53.0 \%$, and $63.7 \%$, respectively. Thus, the results of the chemical analyses agreed well with those of in vitro analyses.

\section{Seasonal variation}

Dry matter content of pricklypear was lowest in June $(14.6 \%)$. It progressively increased to a high of $45.8 \%$ in February (Fig. 4). Apparent dry matter digestibility decreased from September through January at the same time that dry

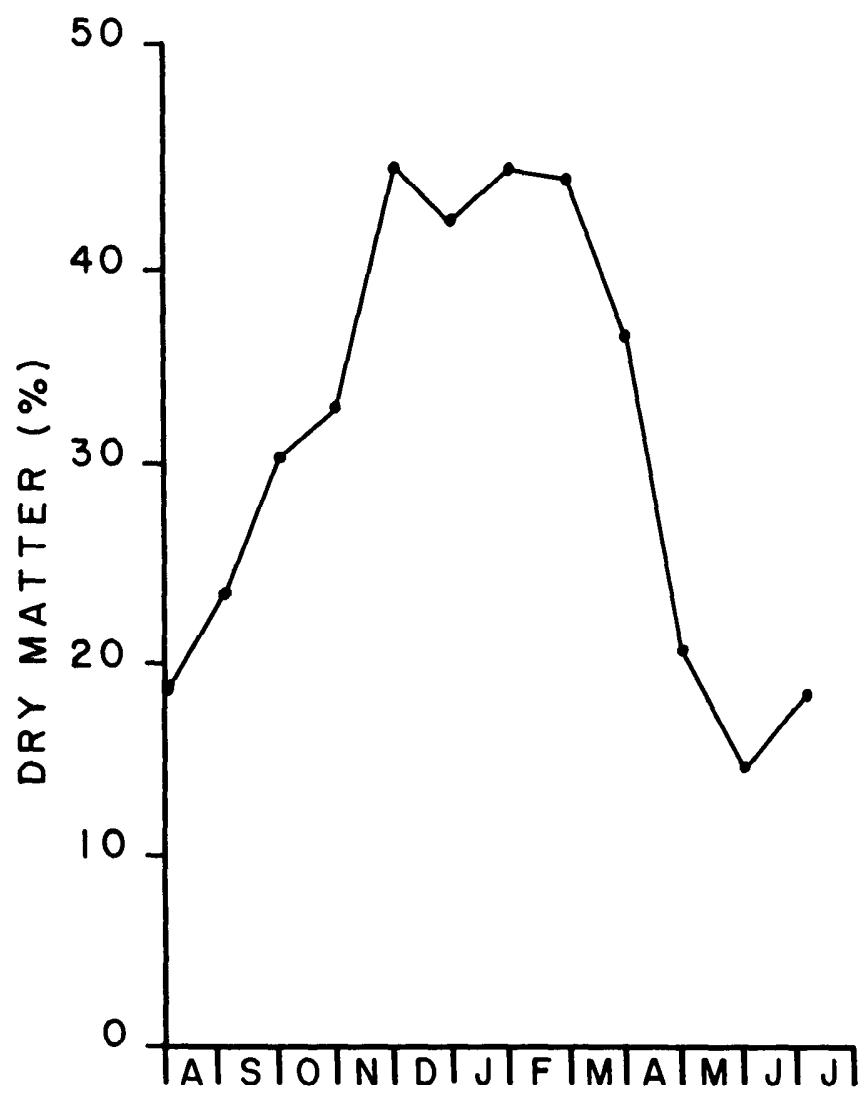



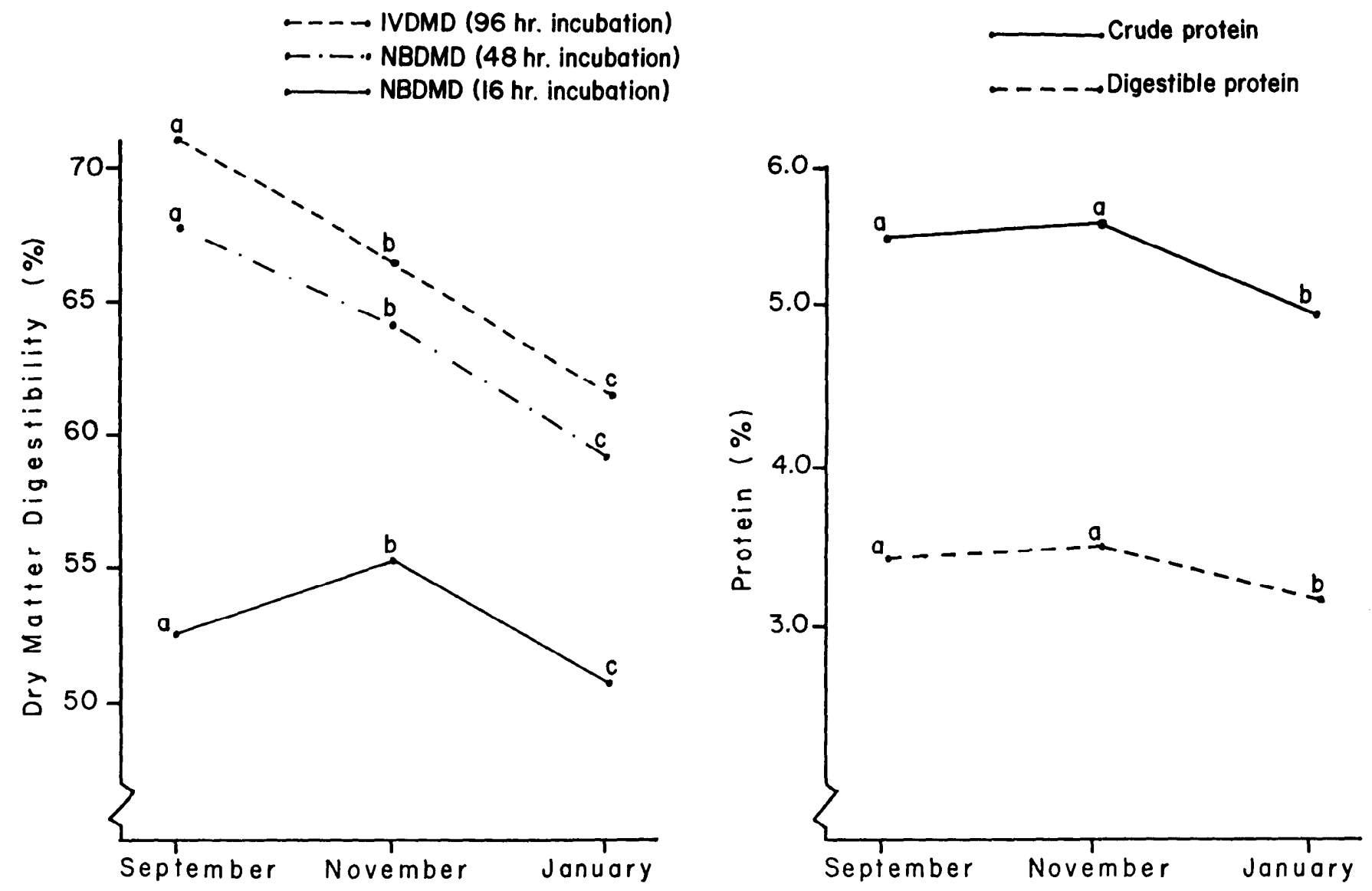

Fig. 5. Apparent dry matter digestibility of plains pricklypear by nylon hag (NBDMD) and in vitro (IVDMD) methods. Means for given incubation method with different letters differ significantly at 5\% level.

matter increased (Figs. 4 and 5). However, no other analyzed constituent changed appreciably from September to January (Fig. 6 and Table 6), nor did the digestion prediction equation (Van Soest 1967) indicate a decrease in digestibility from September through January.

\section{Conclusions}

We concluded that singed plains pricklypear is a palatable and nutritious cattle feed. Therefore, it should be evaluated as an addition to the normal winter feed of shortgrass range. It may be especially valuable for speeding the growth of replacement heifers so they can be bred as yearlings. Because of its relatively high content of soluble carbohydrates, the feeding of pricklypear might make the use of nonprotein nitrogen supplements feasible on shortgrass range. The value of pricklypear control must be determined more completely because it bears on the

Table 6. Chemical composition (\%) of singed plains pricklypear during September, October, and November. ${ }^{1}$

\begin{tabular}{|c|c|c|c|}
\hline Constituent & September & November & January \\
\hline Total ash & $13.0 \mathrm{~b}$ & $12.7 \mathrm{~b}$ & $14.9 \mathrm{a}$ \\
\hline Neutral detergent fiber (NDF) & $32.8 \mathrm{~b}$ & $35.7 \mathrm{a}$ & $33.7 \mathrm{~b}$ \\
\hline Acid detergent fiber (ADF) & $22.9 \mathrm{a}$ & $23.9 \mathrm{a}$ & $23.2 \mathrm{a}$ \\
\hline Acid detergent lignin (ADL) & $8.3 \mathrm{a}$ & $7.4 \mathbf{a}$ & $7.7 \mathrm{a}$ \\
\hline Soluble portion & $67.3 \mathrm{a}$ & $64.3 \mathrm{~b}$ & $66.4 \mathrm{ab}$ \\
\hline Hemicellulose & $9.8 \mathrm{a}$ & $11.8 \mathrm{a}$ & $10.4 \mathrm{a}$ \\
\hline Cellulose & $1.7 \mathrm{a}$ & $3.8 \mathrm{a}$ & $0.7 \mathrm{~b}$ \\
\hline Soluble carbohydrates & $61.8 \mathrm{a}$ & $58.7 \mathrm{~b}$ & $61.5 \mathrm{a}$ \\
\hline
\end{tabular}

Means on the same line followed by different letters differ significantly at $5 \%$ level.

Fig. 6. Crude protein and digestible protein of plains pricklypear during September, November, and January 1974-75. Means for given protein with different letters differ significantly at $5 \%$ level.

economy of feeding pricklypear. The high gains made by the heifers fed pricklypear in addition to the basal ration, plus the evidence of rapid digestion of its energy fractions, appear to warrant research to develop prototype machinery and other methods for singeing pricklypear for converting it to a forage to be fed on the range.

\section{Literature Cited}

Association of Official Agricultural Chemists (A.O.A.C.). 1970. Official methods of analysis. 11 th ed. Ass. Offic. Agr. Chem., Washington, D.C. $957 \mathrm{p}$.

Belasco, I. J., M. F. Gribbins, and D. W. Kollerman. 1958. The response of rumen microorganisms to pasture grass and pricklypear cactus following foliar application of urea. J. Anim. Sci. 17:298-303.

Bement, R. E. 1968. Plains pricklypear: Relation to grazing intensity and blue grama yield on Central Great Plains. J. Range Manage. 21:83-86.

Bond, James, and J. N. Wiltbank. 1970. Effect of energy and protein on estrus, conception rate, growth and milk production of beef females. J. Anim. Sci. 30:438-444.

Church, D. C. 1975. Digestive physiology and nutrition of ruminants, I. 2nd ed. Distributed by O \& B Books, Corvallis, Ore. 673 p.

Clanton, D. C. 1973. Developing of replacement heifers. Proc., the range beef cow: A symposium on production, III. Dec. 17-19, 1973, Rapid City, S. Dak. Univ. of Nebraska, Lincoln. p. 51-63.

Crampton, E. W., and L. E. Harris. 1969. Applied animal nutrition. 2nd ed. W. H. Freeman and Company, San Francisco, Calif. 749 p.

Danley, M. M., and R. L. Vetter. 1971. Changes in carbohydrate and nitrogen fractions and digestibility of forages: Methods of sample processing. J. Anim. Sci. 33:1072-1077.

Goering, H. K., and P. J. Van Soest. 1970. Forage fiber analyses (apparatus, reagents, procedures, and some applications). U.S. Dep. Agr., Agr. Handbook No. $379.12 \mathrm{p}$. 
Griffiths, D. 1905. The pricklypear and other cacti as food for stock. U.S. Dep. Agr., Bur. Plant Ind. Bull. 74. 46 p.

Grifnths, D. 1912. The thomless prickly pears. U.S. Dep. Agr., Farmers Bull. 483. $20 \mathrm{p}$.

Healy, W. B. 1973. Nutritional aspects of soil ingestion by grazing animals. p. 567-588. In: G. W. Butler and R. W. Baily (Ed.). Chemistry and biochemistry of herbage. Vol. 1. Academic Press, New York.

Hoffman, G. D., and R. A. Darrow. 1955. Pricklypear, good or bad? Texas Agr. Exp. Sta. Bull. 806. 12 p.

Karns, W. J. 1952. Cowboys with blowtorches. Compressed Air Magazine 57:190-193.

Maynard, L. A., and J. K. Loosli. 1969. Animal nutrition. 6th ed. McGrawHill Book Company, New York. 613 p.

National Research Council (NRC). 1970. Nutrient requirements of domestic animals. No. 4 Nutrient requirements of beef cattle. 4 th revised ed. Nat. Res. Counc., Washington, D.C. 55 p.

Pinney, D. O., D. F. Stephens, and L. S. Pope. 1972. Lifetime effects of winter supplemental feed level and age at first parturition on range beef cows. J. Anim. Sci. 34:1067-1074.
Shoop, M. C., and D. N. Hyder. 1976. Growth of replacement heifers on shortgrass ranges of Colorado. J. Range Manage. 29:4-8.

Tilley, J. M. A., and R. A. Terry. 1963. A two-stage technique for in vitro digestion of forage crops. J. Brit. Grassland Soc. 18:104-111.

Van Dyne, G. M. 1962. Micro-methods for nutritive evaluation of range forages. J. Range Manage. 15:303-313.

Van Soest, P. J. 1965. Use of detergents in analysis of fibrous feeds. III. Study of effects of heating and drying on yield of fiber and lignin in forages. J. Ass Offic. Chem. 48:785-790.

Van Soest, P. J. 1967. Development of a comprehensive system of feed analyses and its application to forages. J. Anim. Sci. 26:119-127.

Van Soest, P. J., and R. H. Wine. 1967. Use of detergents in the analysis of fibrous feeds. IV. Determination of plant cell wall constituents. J. Ass. Offic. Agr. Chem. 50:50-55.

Wiltbank, J. N. 1972. Management of heifer replacements and the brood cow herd through the calving and breeding periods, p. 150-187. In: C. C. O'Mary and I. H. Dyer (Ed.), Commercial beef cattle production. Lea and Febiger, Philadelphia, $\mathrm{Pa}$.

Woodward, T. E., W. F. Turner, and D. Griffiths. 1915. Pricklypear as feed for dairy cows. J. Agr. Res. 4:405-450. 